\title{
Reduction of the Impact of Fertilization and Irrigation On Processes in the Nitrogen Cycle in Vegetable Fields with BMPs 1
}

\section{Eve-Marie Cockx and Eric H. Simonne ${ }^{2}$}

The nitrogen $(\mathrm{N})$ cycle is a set of transformations that affect $\mathrm{N}$ in the biosphere. Through a series of microbial transformations in the soil, $\mathrm{N}$ is made available to vegetable crops. Thus, knowledge of this cycle by which $\mathrm{N}$ passes from air to soil to organisms and back to air, and how the components of the cycle are affected by human activities, is required to design effective strategies for decreasing undesirable losses of $\mathrm{N}$ from vegetable production to the environment.

Adequate management of fertilization and irrigation has always been recognized as one of the keys to successful vegetable production in Florida. Thus, fertilization and irrigation practices have aimed at supplying enough nutrients and water to ensure economical yields. Since up to $200 \mathrm{lbs} / \mathrm{A}$ of exogenous $\mathrm{N}$ are recommended for vegetable production in Florida, and fertilizer use efficiency seldom exceeds $75 \%$, it is likely that fertilization affects the $\mathrm{N}$ cycle. Best Management Practices (BMPs) aim at reconciling the needs of economical vegetable crop production with those of environmental protection. Effective BMP implementation, therefore, requires an understanding of how current cultural practices affect certain processes in the $\mathrm{N}$ cycle in commercial vegetable fields. It is likely that a complete understanding of these issues by farmers and vegetable professionals will be a prerequisite for the success of the BMP program.

The goals of this article are to (1) present the $\mathrm{N}$ cycle as it relates to crop production, (2) describe how fertilization and irrigation affect the processes within $\mathrm{N}$ cycle, and (3) explain how the proposed BMPs may help reduce the negative environmental impact of these cultural practices.

\section{The Nitrogen Cycle in a Typical Ecosystem}

Because the N cycle is a "cycle", it has no clear beginning and no end (Pidwirny, 2002). Hence, for the sake of presentation, this description of the cycle starts with $\mathrm{N}$ in the soil organic matter where $\mathrm{N}$ is in the form of amino acids, proteins, and nucleic acids (Fig. 1). In the soil, $\mathrm{N}$ found in decomposing organic matter may be converted into inorganic $\mathrm{N}$ forms by soil microorganisms (bacteria and fungi) in

1. This document is HS, one of a series of the Horticultural Sciences Department, Florida Cooperative Extension Service, Institute of Food and Agricultural Sciences, University of Florida. Publication date: September 2003. Please visit the EDIS Web site at http://edis.ifas.ufl.edu.

2. Eve-Marie Cockx, short-term scholar, Eric H. Simonne, assistant professor, Horticultural Sciences Department, Cooperative Extension Service, Institute of Food and Agricultural Sciences, University of Florida, Gainesville, 32611.

The Institute of Food and Agricultural Sciences is an equal opportunity/affirmative action employer authorized to provide research, educational information and other services only to individuals and institutions that function without regard to race, color, sex, age, handicap, or national origin. For information on obtaining other extension publications, contact your county Cooperative Extension Service office. Florida Cooperative Extension Service/Institute of Food and Agricultural Sciences/University of Florida/Christine Taylor Waddill, Dean. 
a process called mineralization (step 1). These bacteria and fungi, also called decomposers, may be found in the upper soil layer. They chemically transform the $\mathrm{N}$ found in organic matter from amino- $\mathrm{N}\left(\mathrm{NH}_{2}\right)$ to ammonium $\left(\mathrm{NH}_{4}^{+}\right)$(Pidwirny, 2002).

Step 1: Organic matter ---> Ammonium

$$
\mathrm{R}-\mathrm{NH}_{2}--->\mathrm{NH}_{4}^{+}
$$

As this fixation is reversible, $\mathrm{NH}_{4}^{+}$may be released from the colloids by way of cation exchange. When released, $\mathrm{NH}_{4}^{+}$may be chemically altered into nitrite $\left(\mathrm{NO}_{2}^{-}\right)$by a specific type of autotrophic bacteria belonging to the genus Nitrosomonas organisms. Nitrosomonas can synthesize their own organic $\mathrm{N}$ compounds from inorganic $\mathrm{N}$ sources (step 3a). Then, $\mathrm{NO}_{2}{ }^{-}$may be quickly converted into nitrate $\left(\mathrm{NO}_{3}{ }^{-}\right)$by another type of bacteria belonging to the

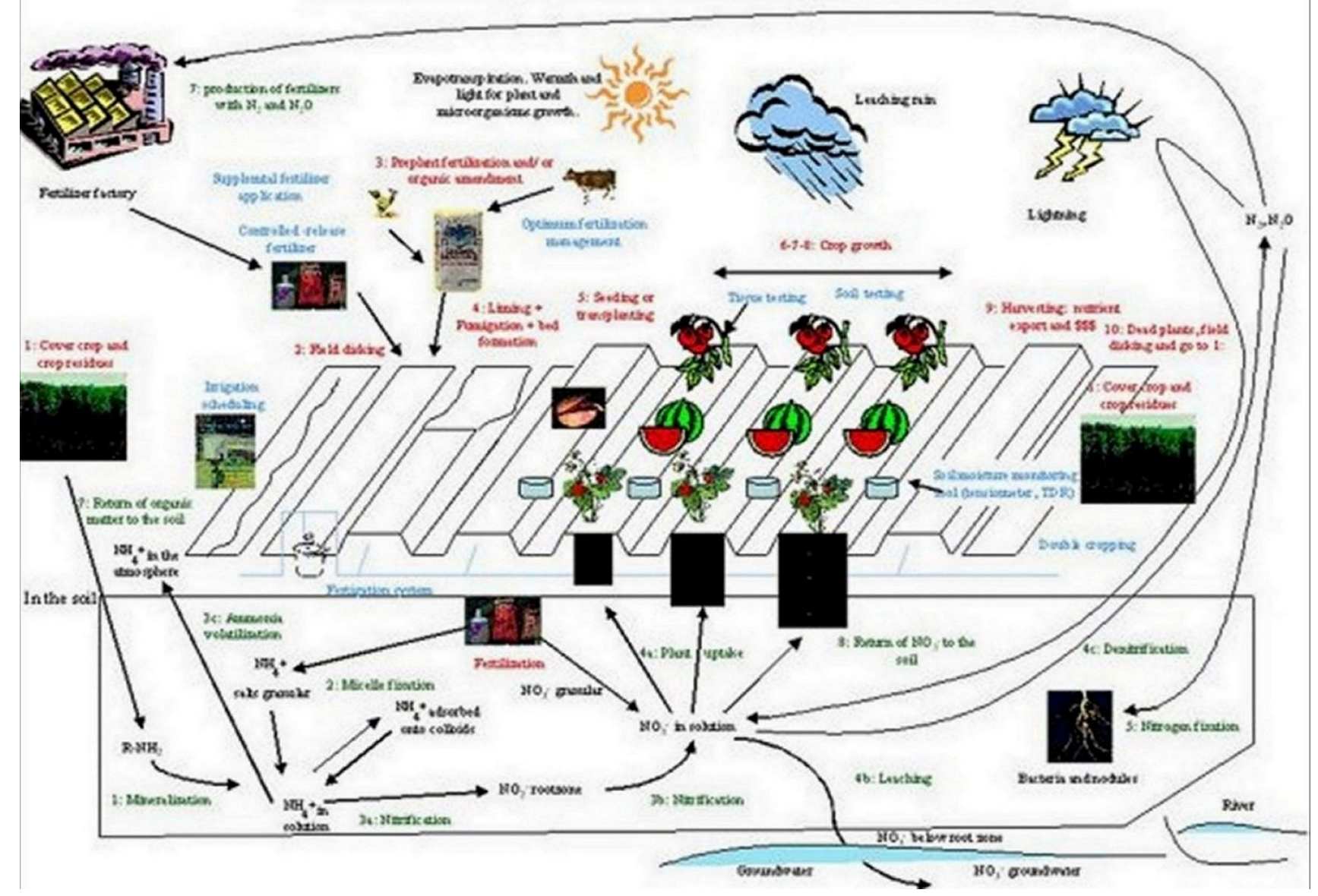

Figure 1. Impact of fertilization, irrigation and other cultural practices in vegetable fields (in red) on the steps of nitrogen cycle (in green) with best management practices (in blue).

Nitrogen in the form of $\mathrm{NH}_{4}^{+}$can then be adsorbed (step 2) onto the surfaces of clay particles in the soil. The $\mathrm{NH}_{4}$ ion that has a positive charge may be held by soil colloids because they have a negative charge. This process is called micelle fixation (Pidwirny, 2002).

Step 2: Ammonium in solution ---> absorbed ammonium ---> ammonium back into solution

$\mathrm{NH}_{4}^{+}$aqueous ---> $\mathrm{NH}_{4}^{+\ldots-\text { - }}$ soil colloid ---> $\mathrm{NH}_{4}^{+}$aqueous genus Nitrobacter (step 3b). Both of these processes involve chemical oxidation and together are known as nitrification (Pidwirny, 2002; Mahendrappa et al., 1966). Both bacteria utilize the energy released by the oxidation of $\mathrm{N}$ compounds in their metabolism of which $\mathrm{NO}_{2}{ }^{-}$and $\mathrm{NO}_{3}{ }^{-}$are by-products of their metabolic pathways. This 2-step process involves a complex series of reactions that can be summarized as: 
Step 3a: Ammonium in solution ---> nitrite in solution

$$
\begin{aligned}
& 55 \mathrm{NH}_{4}^{+}+76 \mathrm{O}_{2}+109 \mathrm{HCO}_{3}^{-}--->\mathrm{C}_{5} \mathrm{H}_{7} \mathrm{O}_{2} \mathrm{~N}+ \\
& 54 \mathrm{NO}_{2}^{-}+57 \mathrm{H}_{2} \mathrm{O}+104 \mathrm{H}_{2} \mathrm{CO}_{3}
\end{aligned}
$$

Step 3b: Nitrite in solution ---> Nitrate in solution

$$
\begin{aligned}
& 400 \mathrm{NO}_{2}^{-}+\mathrm{NH}_{4}^{+}+4 \mathrm{H}_{2} \mathrm{CO}_{3}+\mathrm{HCO}_{3}^{-}+195 \mathrm{O}_{2} \\
--->\mathrm{C}_{5} \mathrm{H}_{7} \mathrm{O}_{2} \mathrm{~N}+3 \mathrm{H}_{2} \mathrm{O}+400 \mathrm{NO}_{3}^{-} &
\end{aligned}
$$

These equations highlight two important points: nitrification requires oxygen and it affects bulk soil $\mathrm{pH}$. First, approximately $4.3 \mathrm{mg} \mathrm{O}$ are consumed for every $\mathrm{mg}$ of $\mathrm{NH}_{4}^{+}$oxidized into $\mathrm{NO}_{3}^{-}$. Second, a quite substantial amount of alkalinity in the form of $\mathrm{HCO}_{3}{ }^{-}$is consumed when $\mathrm{NH}_{4}{ }^{+}$is oxidized, thereby, indirectly decreasing soil pH (Anon., 1999).

The rate of step $3 \mathrm{a}\left(\mathrm{NH}_{4}^{+}\right.$transformed to $\left.\mathrm{NO}_{2}{ }^{-}\right)$ is slower than that of step $3 \mathrm{~b}$. Hence, $\mathrm{NO}_{2}{ }^{-}$does not normally accumulate in soils, but $\mathrm{NO}_{3}^{-}$may. Because $\mathrm{NO}_{3}{ }^{-}$has a negative charge, it may not be adsorbed onto the soil colloids. As most $\mathrm{NO}_{3}{ }^{-}$salts (such as potassium nitrate, calcium nitrate, magnesium nitrate) have high solubility (high Ksp), most $\mathrm{NO}_{3}{ }^{-}$ stays in the soil solution.

If $\mathrm{NH}_{4}{ }^{+}$is neither adsorbed onto soil colloids nor transformed in $\mathrm{NO}_{3}{ }^{-}$, it may be volatilized (step $3 c)$. However, this occurs rather in agricultural ecosystems where fertilizers (urea and manure) are added, than in undisturbed ecosystems.

Step 3c: $\mathrm{NH}_{4}{ }^{+}$in the soil ---> $\mathrm{NH}_{3}$ in the air

Nitrate and $\mathrm{NH}_{4}^{+}$in the soil solution are the most common forms of $\mathrm{N}$ taken up by vegetable crops. Nitrogen uptake is the most important step of the $\mathrm{N}$ cycle in vegetable production.

Step 4a: Ammonium in solution ---> Ammonium inside the root

$\mathrm{NH}_{4}^{+}$aqueous ---> $\mathrm{NH}_{4}^{+}$inside the root

Nitrate in solution ---> Nitrate inside the root

$\mathrm{NO}_{3}{ }^{-}$aqueous ---> $\mathrm{NO}_{3}{ }^{-}$inside the root

In plant nutrition, $\mathrm{N}$ is an essential element. Nitrogen is involved in the composition of all amino acids, proteins and many enzymes. Nitrogen is also part of the puric and pyrimidic bases, and therefore is a constituent of nucleic acids (Mills and Jones, 1996). Typically, $\mathrm{N}$ content in plants ranges between $1.0 \%$ and $6.0 \%$ of the dry weight in leaf tissues (this means that 1 to $6 \mathrm{~g}$ of $\mathrm{N}$ may be found in $100 \mathrm{~g}$ of dry tissue). Under $\mathrm{N}$ shortage, plants grow slowly and are weak and stunted (Mills and Jones, 1996).

Nitrate and $\mathrm{NH}_{4}^{+}$should be regarded as two different nutrients because they affect plant metabolism differently. Nitrate is negatively charged, while $\mathrm{NH}_{4}^{+}$is positively charged. As nutrient uptake is a process that is electrically neutral, it does not involve any net change in plant electric charge. The absorption of $\mathrm{NO}_{3}{ }^{-}$requires the concomitant uptake of a cation or the release of an anion $\left(\mathrm{OH}^{-}\right.$or organic acid). Similarly, the absorption of $\mathrm{NH}_{4}{ }^{+}$when the accompanying ions are $\mathrm{H}^{+}$or $\mathrm{OH}^{-}$, affects soil $\mathrm{pH}$. Hence, $\mathrm{NH}_{4}^{+}$uptake may depress the uptake of the essential cations $\left(\mathrm{K}^{+}, \mathrm{Ca}^{2+}, \mathrm{Mg}^{2+}\right)$.

Another difference between $\mathrm{NO}_{3}{ }^{-}$and $\mathrm{NH}_{4}{ }^{+}$is that $\mathrm{NO}_{3}{ }^{-}$may be stored in the plant before it is used, whereas $\mathrm{NH}_{4}^{+}$needs to be detoxified. Ammonium must be rapidly incorporated into organic molecules because free $\mathrm{NH}_{4}^{+}$disrupts the photosynthesis mechanism by uncoupling redox reactions and affecting the photosynthetic membrane stacks (grana) in chloroplasts. On the contrary, free $\mathrm{NO}_{3}{ }^{-}$is not toxic and it can be stored in the plant until utilized or incorporated into organic molecules by the light-activated enzyme nitrate reductase (NR), after being reduced into $\mathrm{NH}_{2}$ group. Reduced $\mathrm{NO}_{3}{ }^{-}$is added to a glutamic acid residue in a transammination reaction that generates glutamine (Mengel and Kirkly, 1987; Mills and Jones, 1996). Differences in $\mathrm{NO}_{3}{ }^{-}$and $\mathrm{NH}_{4}{ }^{+}$effects on plant growth can be summarized in the old saying: " $\mathrm{NH}_{4}{ }^{+}$greens a plant, while $\mathrm{NO}_{3}^{-}$grows a plant."

Consequently, an optimum $\mathrm{NO}_{3}-\mathrm{N}: \mathrm{NH}_{4}-\mathrm{N}$ ratio exists for vegetable production. The optimum $\mathrm{NO}_{3}-\mathrm{N}$ $: \mathrm{NH}_{4}-\mathrm{N}$ ratio for vegetables grown in hydroponics is 75 : 25 (Marti and Mills, 1991; Sasseville and Mills, 1979; Simonne and Mills, 1991). When $\mathrm{NH}_{4}^{+}$is the dominant form of $\mathrm{N}$ available for plant uptake, a smaller plant will result. When the root system is in fact overloaded in its ability to detoxify absorbed $\mathrm{NH}_{4}^{+}$, then $\mathrm{NH}_{4}^{+}$will be translocated to the top 
portion of the plant. There, carbon sources otherwise used for leaf and stem growth are instead used into detoxification of the $\mathrm{NH}_{4}^{+}$. Protein synthesis pathway dominates the production of the cell wall (Mills and Jones, 1996; Marti and Mills, 1991; Sasseville and Mills, 1979).

If $\mathrm{NO}_{3}{ }^{-}$is not taken up by the roots, it can be transported below the root zone and leached (step $4 \mathrm{~b}$ ) or denitrified (step 4c). As $\mathrm{NO}_{3}{ }^{-}$is soluble in water, it is easily leached from the root zone by excessive rainfall or irrigation (step 4b). In Florida sandy soils, the bottom of the root zone is typically 12 inches for shallow-rooted crops and 3 feet for deepest rooted vegetable crops. The actual rooting depth of vegetables may be limited by the presence of compaction layers, acidic layers, or a spodic horizon.

Step 4b: Nitrate in the root zone ---> Nitrate in the groundwater

$\mathrm{NO}_{3}{ }^{-}$in the root zone $--->\mathrm{NO}_{3}{ }^{-}$in the groundwater

Because the water holding capacity of Florida sandy soils is typically $10 \%(\mathrm{v}: \mathrm{v})$, the top 12 inches soil can hold 1 inch of water. Hence, rainfall of 3 inches in 3 days, or 4 inches in 7 days are considered to be leaching rains that take $\mathrm{NO}_{3}{ }^{-}$below the root zone (Simonne and Hochmuth, 2003 b).

Once below the root zone, $\mathrm{NO}_{3}{ }^{-}$easily enters the hydrologic system. Karst geology is commonly found throughout Florida. A sand layer of variable thickness covers a limestone base (Fig. 2). Through repeated wet/dry cycles, limestone slowly dissolves, creating swales and sinkholes. Through sinkholes, leaching rain is directly in contact with groundwater and is not filtered; $\mathrm{NO}_{3}{ }^{-}$may be found in underground water, springs and in the streams.

Elevated $\mathrm{NO}_{3}{ }^{-}$concentration in ground water has been associated with water quality/health issues and eutrophication. First, short-term exposure to drinking water with a $\mathrm{NO}_{3}{ }^{-}-\mathrm{N}$ concentration above $10 \mathrm{mg} / \mathrm{L} \mathrm{NO}_{3}-\mathrm{N}$ is a potential health problem primarily for infants. Their immature digestive systems are more likely than adult digestive tracts to allow the reduction of $\mathrm{NO}_{3}{ }^{-}$to $\mathrm{NO}_{2}{ }^{-}$. In some rare cases, the presence of $\mathrm{NO}_{2}^{-}$in the digestive tract of

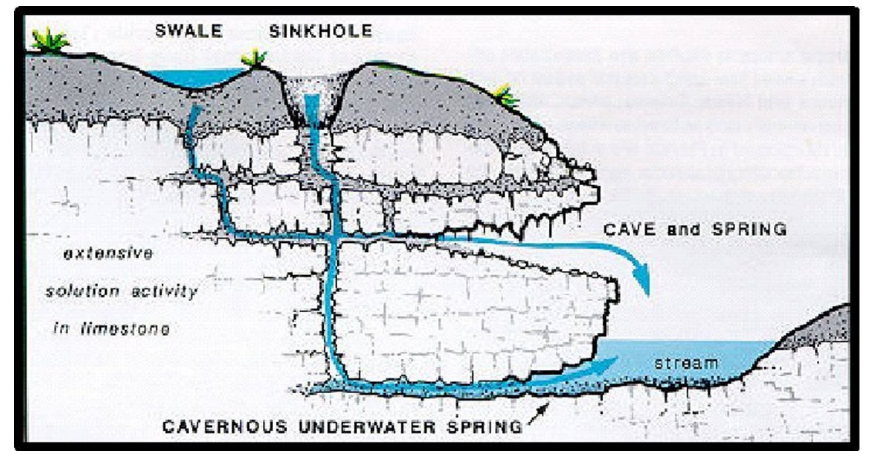

Figure 2. Connection of surface water with groundwater though swales and sinkholes in karst geology found in Florida.

newborns has lead to a disease called methemoglobinemia or "blue baby" syndrome (McCasland et al., 1998).

The second impact of $\mathrm{NO}_{3}{ }^{-}$on water quality is when it accumulates into waterways and causes the eutrophication of N-limited ecosystems.

Eutrophication is a condition in an aquatic ecosystem when exogenous quantities of the limiting factor $(\mathrm{N}$ in north Florida and $\mathrm{P}$ in South Florida) result in algae blooms.

$\mathrm{NO}_{3}^{-}$in waterways ---> $\mathrm{NO}_{3}^{-}$in algae blooms

Algae blooms cloud the water making it difficult for larger submerged aquatic vegetation (SAV) to get enough light and compete for dissolved oxygen. The SAV may dieback thereby reducing available habitat of aquatic animals, which in turns affects the whole food chain in the aquatic ecosystem. In addition, algae blooms increase the Biological Oxygen Demand (BOD), thereby competing with other aquatic animals.

Nitrate that is neither taken up by the plant nor leached may be denitrified. Denitrification (step 4c) occurs commonly in anaerobic soils and is carried out by heterotrophic bacteria. This kind of bacteria must consume energy-rich organic molecules for survival. The most common denitrifying bacteria include several species of Pseudomonas, Alkaligenes and Bacillus. The process of denitrification involves the reduction of $\mathrm{NO}_{3}{ }^{-}$into dinitrogen $\left(\mathrm{N}_{2}\right)$ or nitrous oxide $\left(\mathrm{N}_{2} \mathrm{O}\right)$ gas. Both of these gases then diffuse into the atmosphere (Pidwirny, 2002). No oxygen is required for this process that occurs in anoxic conditions. On the contrary, oxygen is produced and 
may be used by nitrifying bacteria in other layers of the soil. Denitrifying bacteria use $\mathrm{N}$ as the final electron acceptor in their metabolism. Denitrified N in the form of $\mathrm{N}_{2} \mathrm{O}$ or $\mathrm{N}_{2}$ forms joins the largest store of $\mathrm{N}$ in the cycle found in the atmosphere (Shroder, 1981). The atmospheric store is estimated to be approximately one million times larger than the total $\mathrm{N}$ contained in all living organisms.

Step 4c: Nitrate in soil ---> $N$ oxides gases in the atmosphere + Oxygen

$$
\mathrm{NO}_{3}{ }^{-} \text {in soil ---> } \mathrm{N}_{2} \mathrm{O} \text { and } \mathrm{N}_{2} \text { forms in the }
$$
atmosphere + Oxygen

Dinitrogen in the atmosphere may return to earth by three ways: rain (step 5a), fertilizer production (step 5b), or N fixation (step 5c). Small proportions of atmospheric $\mathrm{N}_{2}$ return to the soil in rainfall or through the effects of lightning; an estimated $10^{13} \mathrm{~g}$ per year of $\mathrm{N}_{2}\left(22,000\right.$ Million lbs per year of $\left.\mathrm{N}_{2}\right)$ are fixed and transformed in ammonia by lightning (Kimball, 2003). Nitrogen fertilizers are produced by condensation of $\mathrm{N}_{2}$ and $\mathrm{H}_{2}$ which produces $\mathrm{NH}_{3}$ (Haber-Bosch process; Anon., 2003b).

Step 6: Dinitrogen + Dihydrogen ---> Ammonia + energy b, 2003)

$\mathrm{N}_{2}(\mathrm{~g})+3 \mathrm{H}_{2}(\mathrm{~g})--->2 \mathrm{NH}_{3}(\mathrm{~g})+$ energy (Anon

The bulk $\mathrm{N}_{2}$ returned to earth, however, is biochemically fixed in the soil by specialized micro-organisms like bacteria, actinomycetes, and cyanobacteria. This process is called nitrogen fixation (step 5). It may occur in plants that harbor nitrogen-fixing bacteria within their root nodules. Free-living bacteria may also fix $\mathrm{N}_{2}$, but on a smaller scale. The amounts of $\mathrm{N}$ fixed by free-living, non-photosynthetic bacteria in the soil may achieve an approximate maximum of $15 \mathrm{~kg} / \mathrm{ha} /$ year $(13.4$ lbs/A/year).

Step 5: Dinitrogen in the air ---> Ammonia for the plant

$\mathrm{N}_{2}$ in the air ---> $\mathrm{NH}_{3}$ for the plant

Biological nitrogen fixation can be represented by the following equation, in which two units of ammonia are produced from one unit of nitrogen gas, at the expense of 16 units of ATP (energy) and a supply of electrons and protons (hydrogen ions):

$$
\begin{aligned}
& \text { Step 5: } \mathrm{N}_{2}+8 \mathrm{H}^{+}+8 \mathrm{e}^{-}+16 \mathrm{ATP}--->2 \mathrm{NH}_{3}+ \\
& \mathrm{H}_{2}+16 \mathrm{ADP}+16 \mathrm{Pi} \text { (Anon, 2003a) }
\end{aligned}
$$

The low $\mathrm{N}$ contribution of the free-living, non photosynthetic bacteria, is the result of limited availability of suitable organic substrates (energy sources) and low bacterial populations in the soil environment. Nitrogen fixation is characteristically higher in tropical soils, where substrate availability, temperature and moisture are more favorable to the maintenance and activity of an actively growing bacterial population (Hubell and Kiddler, 1998).

The best-studied example of $\mathrm{N}$ fixation is the association between legumes and bacteria in the genus Rhizobium. The main legume crops commercially grown in Florida are peanuts (Arachis hypogaea), snap bean (Phaseolus vulgaris) and pink-eyed and black-eyed pea (Vigna unguiculata). These Rhizobium and legumes are able to survive independently (soil nitrates must then be available to the legume), but this association is beneficial to both organisms. In exchange for some $\mathrm{N}$, bacteria receive carbohydrates from the plants. Special structures (nodules) in roots allow them to be connected with the roots of the plant. Scientists estimate that biological fixation globally adds approximately 140 million metric tons of $\mathrm{N}$ to soil and sea ecosystems every year. However, the actual amount of $\mathrm{N}$ fixed in each ecosystem depends on the environmental conditions and the nature of biological system(s) present, which are capable of $\mathrm{N}$ fixation. Nitrogen fixation rates may vary from almost 0 up to 1,000 $\mathrm{Kg} / \mathrm{ha} /$ year (892 lbs/A/year) (Hubell and Kiddler, 1998).

The last step of the $\mathrm{N}$ cycle is the return of organic matter to the soil (Step 7). Organic matter returns to the soil in the form of crop residues, incorporation of cover crops, and/or organic amendments such as compost or manure. This organic matter will be mineralized and then, follow the steps of the cycle again. 
The $\mathrm{N}$ cycle described above, (from the mineralization of organic matter to the return to the soil of organic matter) occurs in an undisturbed ecosystem. However, higher vegetable yields may be achieved with intensive production practices, fertilization and irrigation. Therefore, vegetable production may affect some steps of the $\mathrm{N}$ cycle.

\section{Impact of Fertilization, Irrigation and Other Production Practices Used for Vegetable Production on the Processes in the Nitrogen Cycle}

Vegetable production does not alter the $\mathrm{N}$ cycle. Instead, vegetable production may change the relative importance of some parts of the N-cycle. Cultural practices affect the $\mathrm{N}$ cycle in vegetable fields either directly by (1) modifying soil microorganism population (fumigation), (2) adding $\mathrm{N}$ to the root zone (fertilization), (3) affecting water movement (irrigation), or indirectly by changing temperature (mulching), $\mathrm{pH}$ (liming) or adding organic carbon source into the root zone (cover crop).

Soil fumigation is a chemical or physical process that kills viable weeds, seeds, soil-borne pathogens (mainly Phytopthora and Pythium species) and nematodes (rootknot, ring or sting species).

For approximately 30 years, the vegetable industry in Florida has relied on methylbromide and chloropicrin mixture as broad-spectrum soil fumigants. With the complete phase out of methyl bromide by 2005 in the US as a part of the Vienna convention for the protection of the ozone layer (Anon., 1985) modified by the Montreal (Anon., 1987) and Kyoto (Anon., 1992) protocols, alternative fumigants, such as metam sodium (sodium-N-methyldithiocarbamate), metam potassium (potassium-N-methyldithiocarbamate) and 1,3 dichloropropene (Telone) are under evaluation (Motis and Locascio, 2002; Locascio and Dickson, 2002; Hochmuth and Davis, 2002). Because they are biocides, these soil fumigants kill not only pathogenic microorganisms, but also beneficial soil microorganisms, including Nitrosomonas and Nitrobacter which are responsible for nitrification. It is estimated that soil microorganism populations reach their pre-fumigation levels approximately 2 to 3 weeks after fumigation. Therefore, soil fumigation, regardless of the type of fumigant used, slows nitrification, which results in less $\mathrm{NH}_{4}^{+}$being converted into $\mathrm{NO}_{3}{ }^{-}$(step 3a, 3b) (Fig. 3). The decrease in nitrification after fumigation suggests that producers using fumigants may need to adjust their starter fertilizer applications on vegetable crops and apply $\mathrm{N}$ in the $\mathrm{NO}_{3}{ }^{-}$form rather than the $\mathrm{NH}_{4}{ }^{+}$form. Nitrate is then available for the vegetable crop (Welsh et al. , 1996).

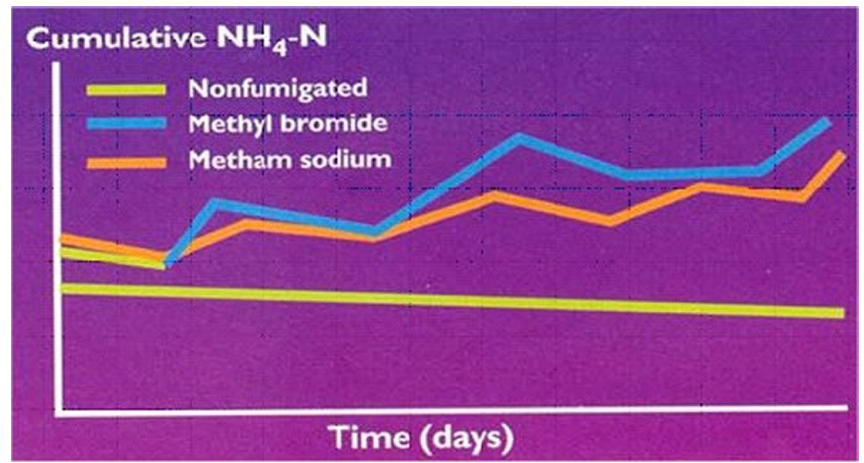

Figure 3. Effect of soil fumigation on the level of $\mathrm{NH}_{4}^{+}$ converted into $\mathrm{NO}_{3}{ }_{3}$, during nitrification process. Credits: Source: Welsh et ăl., 1996.

Fertilization is the second cultural practice that directly affects the $\mathrm{N}$ cycle in the root zone of vegetable crops. Fertilization affects not only plant uptake, but also mineralization, nitrification, and denitrification and ammonia volatilization (Table 1). When fertilizers or salts are added to the soils, microorganisms compete with vegetable crops for $\mathrm{NO}_{3}{ }^{-}$and $\mathrm{NH}_{4}{ }^{+}$. Thus, additions of fertilizers increase formation of the final product of each process described above by increasing the activity of bacteria. Typical $\mathrm{N}$ fertilizer efficiency ranges only between $40 \%$ and $60 \%$. The equation of urea hydrolysis shows how losses can occur, particularly of ammonia.

Urea hydrolysis: $\mathrm{CO}\left(\mathrm{NH}_{2}\right)_{2}+\mathrm{H}^{+}+2 \mathrm{H}_{2} \mathrm{O}--->2$ $\mathrm{NH}_{4}^{+}+\mathrm{HCO}_{3}{ }^{-}$

Urea + Hydrogen ion + Water ---> Ammonium + Carbonate

$\mathrm{HCO}_{3}^{-}+\mathrm{H}+--->\mathrm{CO}_{2}+\mathrm{H}_{2} \mathrm{O}$ (added $\mathrm{H}$ lost from soil solution) 
During hydrolysis, soil $\mathrm{pH}$ can increase above 7 because the reaction requires $\mathrm{H}^{+}$from the soil system. In alkaline soils, less $\mathrm{H}^{+}$is initially needed to drive urea hydrolysis on a soil already having low $\mathrm{H}^{+}$. In an alkaline soil, removing more $\mathrm{H}^{+}$(from a soil solution already low in $\mathrm{H}^{+}$), can increase $\mathrm{pH}$ even higher (Anon, 2003e).

$$
\mathrm{NH}_{4}^{+}+\mathrm{OH}^{-}--->\mathrm{NH}_{4} \mathrm{OH}--->\mathrm{NH}_{3}+\mathrm{H}_{2} \mathrm{O}
$$

Irrigation is the third factor that affects the $\mathrm{N}$ cycle and most vegetable crops grown in Florida are irrigated. Although average total rainfall is 50 to 56 inches/year in Florida, rainfall distribution is not adequate for vegetable production and irrigation must be used. In addition, rainfalls of more than $1 \mathrm{inch} /$ day are common, which may create temporary anoxic (anaerobic) conditions in flooded soils. By creating anoxic and then dry conditions, irrigation and rainfall may affect each process of the $\mathrm{N}$ cycle, from mineralization to $\mathrm{N}$ fixation (Table 2). In plasticulture systems, it has been estimated that an irrigation of 24 $\mathrm{gal} / 100 \mathrm{ft}$ results in an inch vertical movement of the water front in a Lakeland fine sand.

Other common cultural practices used in vegetable production and that indirectly affect the $\mathrm{N}$ cycle include plastic mulching, cover crops, and liming.

Polyethylene mulch has been used for commercial vegetable production in Florida for more than 30 years. There are approximately 70,000 acres of mulched vegetables in Florida, ranking it near the top of the US for this production method. Mulching is used because it creates a physical barrier to weeds, it reduces erosion and increases soil moisture and temperature. Thus it influences processes of the $\mathrm{N}$ cycle that are temperature dependant (Table 3).

Cover cropping is another cultural practice that indirectly affects the $\mathrm{N}$ cycle. Growers use cover crops because they reduce erosion, add organic matter (OM) and $\mathrm{N}$ (legume cover crops) to the soil, and because, in some cases, they reduce populations of nematodes. Cover crops also trap residual soil $\mathrm{N}$ and reduce $\mathrm{N}$ loss to ground water. Finally, the addition of $\mathrm{OM}$ and $\mathrm{N}$ (from the cover crop or from crop residues) creates a favorable environment for microbial growth (Wang et al., 2002) and may temporally increase soil water holding capacity of the soil.

Mineralization is affected by the $\mathrm{C}: \mathrm{N}$ ratios of organic amendments (Table 4). Materials rich in $\mathrm{N}$ (having a low $\mathrm{C}: \mathrm{N}$ ratio) favor mineralization (residues of legumes, animal slurry or organic fertilizer based on blood or other proteins). Those with a low content of $\mathrm{N}$ (elevated $\mathrm{C}: \mathrm{N}$ ratio such as cereal straw) favor immobilization, because such materials contain too little $\mathrm{N}$, at least in readily decomposable form, to satisfy the requirement of the microbial population responsible for their decomposition (Haynes, 1986 b). When organic residues with a high $\mathrm{C}: \mathrm{N}$ ratio (sawdust 400:1, oat straw 80:1) are added to agricultural soils, extra fertilizer $\mathrm{N}$ should be added concomitantly in order to lower the $\mathrm{C}: \mathrm{N}$ ratio below 20 to 25 and thus avoid net immobilization and consequent $\mathrm{N}$ deficiency in the vegetable crops (Allison, 1973).

Mineralization is not the only process influenced by addition of OM. Carbon supply (from cover crop, crop residues, or organic amendments) affects denitrification directly by supplying the necessary substrate for growth of denitrifiers and indirectly through the consumption of $\mathrm{O}_{2}$ by other microorganisms that deplete $\mathrm{O}_{2}$ in the soil. When $\mathrm{OM}$ is added to the soil, it increases $\mathrm{C}$ levels and could potentially result in increasing denitrification (Haynes, 1986 b).

Lastly, the presence of a cover crop can decrease the level of nitrate leaching. A lack of vegetation (fallow) for at least part of the year is a key factor stimulating $\mathrm{NO}_{3}{ }^{-}$leaching from arable cropping systems. A major source of groundwater $\mathrm{NO}_{3}{ }^{-}$from agriculture land can originate from post-harvest mineralization of crop residues, rather than from the fertilizer itself. Mineralization usually continues after uptake by an arable crop has ceased, causing a considerable accumulation of nitrate during the late summer and early winter. Only a fraction of this residual fertilizer is absorbed by the following crop, and the remainder is available to leach during the following months. When land is left fallow, after being cropped, leaching can be a particular problem due to rainfall (Powlson, 1993). Therefore, mulching, establishment of cover crops, and crop residues have a direct positive impact on the $\mathrm{N}$ cycle. 
Liming is the third cultural practice that indirectly affects the $\mathrm{N}$ cycle. Lime is applied to (a) eliminate toxicities of $\mathrm{Al}^{3+}$ and $\mathrm{Mn}^{2+}$, (b) supply adequate levels of $\mathrm{Ca}^{2+}$ and $\mathrm{Mg}^{2+}$, (c) facilitate the utilization of water, and (d) increase soil $\mathrm{pH}$ and create conditions which maximize the availability of the essentials nutrients. In addition, it is necessary to apply maintenance doses of lime to offset the acidifying effects of $\mathrm{NH}_{4}$-containing fertilizers (Somner and Yamada, 2002). Soil acidity affects the plant root environment, which ultimately affects plant growth and performance. Most plants grow better in slightly acidic soils rather than in strongly acidic soils. When a soil is too acidic for proper plant growth, lime may be applied to reduce the acidity (Kidder, 1999).

Because acidity determines the general chemical environment in the soil, soil $\mathrm{pH}$ influences the rate of mineralization, nitrification, denitrification and plant uptake. Each of these processes typically proceeds more readily in a neutral or slightly acidic soil than in a strongly acidic soil (Table 5 and Table 6; Haynes, 1986 a, b, c; Haynes and Sherlock, 1986).

In summary, fertilization, irrigation and several other cultural practices also influence the $\mathrm{N}$ cycle. Their effects on it may be favorable. However, these practices may alter the cycle as well. The main disturbance comes from $\mathrm{NO}_{3}{ }^{-}$leaching. Nitrate leaching largely depends on environmental effects and on water movement. Consequently, $\mathrm{NO}_{3}$ leaching may be difficult to control. Intensive irrigation or excessive rainfall may be responsible for important leaching losses. Nutrient BMPs and irrigation scheduling aim at reducing the impact of vegetable production on the $\mathrm{N}$ cycle while maintaining or increasing productivity.

\section{How Water and Nutrient-Management BMPs Can Reduce the Undesirable Side Effects of Cultural Practices on the Nitrogen Cycle in Vegetable Fields}

Programs to minimize nonpoint source pollutants on surface and groundwater originated in the Water Pollution Control Act of 1948 and were formally established with the Federal Clean Water Act (FCWA) of 1977. Section 303(d) of the FCWA requires states to identify impaired water bodies and establish total maximum daily loads (TMDL). A TMDL is a calculation of the maximum amount of a pollutant that a water body can assimilate from point or non-point sources and still meet water quality standards for its intended use (fishing, swimming, and drinking). TMDL involve quantitative analyses of water bodies where one or more water quality standards are not being met, and are aimed at identifying the management strategies necessary to attain those water quality standards. Under section 303(d) of the Clean Water Act, every two years each state must identify bodies that do not meet water quality standards. Water bodies are "water quality-limited" estuaries, lakes, and streams that fall short of surface water quality standards, and that are not expected to improve within the subsequent two years (Anon, 2003e).

Florida has acted to protect water resources through another act, the Surface Water Improvement and Management (SWIM) Act passed in 1987 by the Florida legislature. The SWIM act directed the state to develop management and restoration plans for preserving or restoring priority water bodies. The legislation designated a number of SWIM water bodies including Lake Apopka, Tampa Bay, Indian River Lagoon, Biscayne Bay, St. Johns River, Lake Okeechobee, and the Everglades. Vegetable producing areas are often close to these water bodies. The goals of this act are to protect water quality and natural systems, create governmental and other partnerships, and manage watersheds (Anon, 2003d).

In Florida, water and fertilizer management are inextricably linked. Changes in one will almost inevitably affect the efficiency of the other. The goal of proper water management is to keep both the irrigation water and the fertilizer in the root zone. Therefore, knowledge of the root zone of a particular crop is needed so that water and fertilizer inputs can be managed properly throughout the season (Anon., 2003e).

\section{Best Management Practices (BMPs)}

Best Management Practices (BMPs) are specific cultural practices that aim at reducing the loads of specific compounds while increasing or maintaining 
economical yields. The implementation of BMPs may be key in reducing the consequences of alterations of the $\mathrm{N}$ cycle in vegetable fields. Implementation of BMPs at the farm level is a key to maintaining the quality and the quantity of ground and surface waters. In most cases, BMPs have been determined to be effective for reducing or preventing pollution. The Florida Vegetable and Agronomic Crop Water Quality and Quantity Best Management Practices Manual (Anon., 2003c) will regulate the 142,000 ha, $\$ 1.4$ billion vegetable industry in Florida (Witzig and Pugh, 2001). The seven sections of the manual are Pesticide Management, Conservation Practices and Buffer, Sediment Control, Irrigation and Nutrient Management, Water Resources, Seasonal and Temporary Farming Operations, and Record Keeping and Accountability. Each section is divided into specific BMPs. Each BMP description is 2 to 3 pages long, consisting of a title, pictures, working definition, set of things to do (BMPs), things to avoid (potential pitfalls), supplemental technical criteria, and references (Hochmuth, 2000; Simonne et al., 2003; McCasland et al., 1998).

BMPs should help at reducing the negative impact of cultural practices, particularly on water quality (Table 7). The expected impacts on water quality may be direct or indirect and may lead to different environmental benefits.

Research and growers have helped determine some of the major water and nutrient management practices (Table 8). This information can be used on vegetable farms to ensure that fertilization results in economically viable production without measureable negative impacts on the environment and alteration of the $\mathrm{N}$ cycle.

This article, has described how cultural practices may influence the steps of the $\mathrm{N}$ cycle. They can affect it directly by fertilization, irrigation or fumigation. Other cultural practices such as liming, mulching, establishment of cover crops also affect the cycle but indirectly. These practices create conditions that may or may not be favorable to the $\mathrm{N}$ cycle. However, with the emergence of the BMPs, some remedies against alteration of the cycle seem to give impressive results. The different processes of the nitrogen cycle, how fertilization, irrigation and other cultural practices affect them and finally the possible remedies brought about by the BMPs, are summarized in Table 9. BMPs are interconnected and unseparable. They have an indirect effect on water quality. Hence, BMPs should be used together, and the weakest BMP will determine the efficiency of the entire BMP plan.

\section{References}

Agarwal, A.S., B.R., Sing and Kanehiro, Y. 1971. Ionic Effects of Salts on Mineral Nitrogen Release in an Allophonic Soil. Soil Sci. Am. Proc. 35: 454-457.

Allison, F. E. 1973. Soil Organic Matter and Its Role in Crop Production. Elsevier, Amsterdam, NL.

Alexander, M. 1977. Introduction to Soil Microbiology. Wiley and Sons, New York, NY.

Alexander, M. 1980. Effects of Acidity on Microorganisms and Microbial Processes in Soil. In: Effects of Acid Precipitation on Terrestrials Ecosystems (T. C. Hutchinson and M. Havas, eds.), pp. 363-380. Plenum, New York, NY.

Anonymous. 1987. The Montreal protocol on substances that deplete the ozone layer. U.N. Environ. Program. (http://www.unep.ch/ozone/montreal.shtml)

Anonymous. 1985. The Vienna convention for the protection of the ozone layer, U.N. Environ. Program. (http://www.unep.ch/ozone/vienna.shtml)

Anonymous. 1992. The convention and Kyoto protocol. U.N. frame work convention on climate change. (http://unfcc.int/resource/convkp.html)

Anonymous. 1999. Fishdoc, Nitrification at the Heart of Filtration. Accessed on July 17, 2003. (http://www.fishdoc.co.uk/filtration/nitrification.htm)

Anonymous. 2003 a. The Microbial Word, the Nitrogen Cycle and Nitrogen Fixation. Accessed on August 11, 2003.

(http://helios.bto.ed.ac.uk/bto/microbes/nitrogen.htm)

Anonymous. 2003 b. AUS-e-TUTE. Use and Production of Ammonia (Haber Process). Accessed 
on July 18, 2003.

(http://www.ausetute.com.au/haberpro.html)

Anonymous. 2003 c. Office Ag. Water Policy, Best Management Practices, BMP Manuals Currently Under Development, Vegetable and Agronomic Crops Draft (version 3), Introduction. Accessed on July 15, 2003.

(http://www.floridaagwaterpolicy.com/)

Anonymous. 2003 d. Florida, Department of Environmental Protection. Accessed on July 15, 2003. (http://www.dep.state.fl.us/water/tmdl/ background.htm)

Anonymous. 2003 e. Ammonia Volatilization. Accessed on August 15, 2003. (http://www.dasnr.okstate.edu/nitrogen_use/ ammonia.pdf)

Blackmer, A. M. and J. M. Bremner. 1978. Inhibitory Effect of Nitrate on Reduction of $\mathrm{N}_{2} \mathrm{O}$ to $\mathrm{N}_{2}$ by Soil Microorganisms. Soil Biol. Biochem. 10:187-191.

Broebent, F. E. and T. Nakashima. 1971. Effect of Added Salts on Nitrogen Mineralization in Three California Soils. Soil Sci. Soc. Am. Proc. 35: 457-460.

Butler, T. 2003. C:N Ratios of Soil Selected Materials. Accessed on July 11, 2003. (http://stephenville.tamu.edu/ butler/slideshows/ Soils/sld013.htm)

Campbell, C. A. 1978. Soil Organic Carbon, Nitrogen and Fertility. In: Soil Organic Matter. (M. Schnitzer and S. U. Khan, eds.), pp. 173-271. Am. Elsvier, New York, NY.

Campbell, C. A. and V. O. Biederbeck. 1982. Changes in Mineral $\mathrm{N}$ and Numbers of Bacteria and Actinomycetes During Two Years Under WheatFallow in Southwestern Saskatchewan. Can. J. Soil Sci. 62: 125-137.

Campbell, C. A., V. O. Biederbeck and F. G. Warder. 1971. Influences of Stimulated Fall and Spring Condition on the Soil System. Effect on Soil Nitrogen. Soil Sci. Soc. Am. Proc. 35: 480-483.
Combs, T. 2000. Ammonia Volatilization, XIV: (6). Accessed on August 15, 2003. (http://www.hort.wisc.edu/cran/Newsletter/ 2000\%20newsletter/7_5_00\%20newsletter.pdf)

Cowley, N., D. Thompson and C. Henry. 1999. Ammonia Volatilization Study. Accessed on August 15, 2003. (http://faculty.washington.edu/clh/nmanual/ appendixe.pdf)

Frota, J. N. E. and T. C. Tucker. 1972. Temperature Influence on Ammonium and Nitrate Absorption by Lettuce. Soil Sci. Soc. Am. Proc. 36: 97-100.

Giller, K. E. 2001. Nitrogen Fixation in Tropical Cropping Systems. pp. 254-258. CABI Publishing.

Haynes, R. J. and K. M. Goh. 1978. Ammonium and Nitrate Nutrition of Plants. Biol. Rev. Cambridge Philos. Soc. 53: 465-510.

Haynes, R. J. 1986 a. Origin, Distribution and Cycling of Nitrogen in Terrestrials Ecosystems. In: Mineral Nitrogen in the Plant Soil System" (R. J Haynes with contribution by K. C. Cameroun, K. M. Goh, R. R. Sherlock, eds.), pp. 1-51. T. T. Kozlowsky, Univ. of Wisconsin, Madison, WI.

Haynes R. J. 1986 b. The Decomposition Process: Mineralization, Immobilization, Humus, Formation and Degradation, Factors Influencing Decomposition. In: Mineral Nitrogen in the Plant Soil System (R. J Haynes with Contribution by K. C. Cameroun, K. M. Goh, R. R. Sherlock, eds.), pp. 81-109. T. T. Kozlowsky, Univ. of Wisconsin, Madison, WI.

Haynes, R. J. 1986 c. Nitrification, Factors Regulating Nitrification. In Mineral Nitrogen in the Plant Soil System (R. J. Haynes with Contribution by K. C. Cameroun, K. M. Goh, R. R. Sherlock, eds.), pp. 134-149. T. T. Kozlowsky, Univ. of Wisconsin, Madison, WI.

Haynes, R. J. and R. R. Sherlock. 1986. Gaseous Losses of Nitrogen, Denitrification and Nitrification. In: Mineral Nitrogen in the Plant Soil System (R. J. Haynes with Contribution by K. C. Cameroun, K. M. 
Goh, R. R. Sherlock, eds.), pp. 278-283. T. T.

Kozlowsky, Univ. of Wisconsin, Madison, WI.

Heilman, P. 1975. Effect of Added Salts on Nitrogen Release and Nitrate Levels in Forest Soils of the Washington Coastal Area. Soil Sci. Soc. Am. Proc. 39: 778-782.

Hochmuth, G.J. 2000. Nitrogen management practices for vegetable production in Florida. UF/IFAS, Fla. Coop. Ext. Serv., Circ. 1222. (http://edis.ifas.ufl.edu/cv237)

Hochmuth, R.C. and W. E. Davis. 2002. Evaluating Nutsedge Control (Cyperus spp) with Various Formulations and Rates of 1,3-Dichloropropene Chemigated Using Drip Tape Under Two Polyethylene Mulches. Proc. Fla. State Hort. Soc. 115: 195-196.

Hubell, D. H., and G. Kiddler, 1998. Biological Nitrogen Fixation. (http://edis.ifas.ufl.edu/BODY_SS180)

Jones, R. W. and R. A. Hedlin. 1970. Ammonium, Nitrite and Nitrate Accumulation in Three Manitoba Soils as Influenced by Added Ammonium Sulfate and Urea. Can. J. Soil Sci. 50:331-338.

Justice, J. K., and R. L. Smith. 1962. Nitrification of Ammonium Sulfate in a Calcareous Soil as Influenced by a Combination of Moisture, Temperature and Levels of Added N. Soil Sci. Soc. Am. Proc. 26: 246-250.

Kidder, G. 1999. Lime and Liming, a Florida Perspective. UF/IFAS, Fla. Coop. Ext. Serv. Fact Sheet SL-58. (http://edis.ifas.ufl.edu/BODY_SS161)

Kimball, J. W. 2003.The nitrogen Cycle. Accessed on June 30, 2003. (http://users.ren.com/jkimball.ma.ultranet/ BiologyPages/N/NitrogenCycle.html)

Kowalenko, C.G., and D. R. Cameroun. 1976. Nitrogen Transformation in An Incubated Soil as Affected by Combinations of Moisture, Content and Temperature and Adsorption-fixation of Ammonium. Can. J. Soil Sci. 56: 63-77.
Laura, R. D. 1977. Salinity and Nitrogen Mineralization in Soil. Soil Biol. Biochem. 9: 333-336.

Locascio, S. J. and D. W. Dickson. 2002. Alternative Fumigants Applied with Standards and Virtually Impermeable Mulches for Tomato. Proc. Fla. State Hort. Soc. 115: 192-194.

Mahendrappa, M. K., R. L., Smith and A. T. Christianson, 1966. Nitrifying Organisms Affected by Climatic Region in Western United States. Soil Sci. Soc. Am. Proc. 30: 60-62.

Marti, H. R. and H. A. Mills. 1991. Nutrient Uptake and Yield of Sweet Pepper as Affected by Stage of Development and N Form. J. Plant Nutr. 14(11): 1165-1175.

Mattos, Jr, D., A. K. Alva, S. Paramasivam and D. A. Graetz. 2003. Nitrogen Volatilization and Mineralization in a Sandy Entisol of Florida Under Citrus. Commun. Soil Sci. and Plant Anal. 34(13-14): 1803-1824.

McCasland, M., N. M. Trautmann and K. S, Porter. 1998. Natural Resources Cornell Cooperative Extension, Nitrate: Health Effects in Drinking Water. Accessed on July 20, 2003.

(http://pmep.cce.cornell.edu/facts-slides-self/facts/nitheef-grw85.html)

Mengel, K. and E.A. Kirby. 1987. Principles of plant nutrition, 4th edition, Intl. Potash Inst, Bern, Switzerland.

Miller, R. D., and D. D. Johnson. 1969. The Effect of Soil Moisture Tension on $\mathrm{CO}_{2}$ Evolution, Nitrification and Nitrogen Mineralization. Soil Sci. Soc. Am. Proc. 28: 644-647.

Mills, H. A. and J. B. Jones, Jr. 1996. Plant Nutrition and Analysis, Essential Macronutrients. In Plant Analysis Handbook II, pp. 8-15, Macromicro Publishing, Athens, GA.

Motis, T. N. and S. J. Locascio. 2002. Efficacy of 1,3-Dicloropropene + Chloropicrin and Metam-Na on Yellow Nutsedge Tubers Planted at Varying Growth Stages. Proc. Fla. State Hort. Soc. 115: 189-192. 
Myers, R. J. K., Campbell, C. A., and Weier, K. L. 1982. Quantitative Relationship Between Net Nitrogen Mineralization and Moisture Content of Soils. Can. J. Soil Sci. 62: 111-124.

Nyborg, M., and P. B. Hoyt, 1978. Effects of Soil Acidity and Liming on Mineralization of Soil Nitrogen. Can. J. Soil Sci. 58: 331-338.

Olson, S. M. 2003. Mulching. In: Vegetable Production Guide. (S. M. Olson and E. H. Simonne, eds.), pp 25-28. Vance Publishing, Lenexa, KS.

Patrick, W. H. 1982. Nitrogen Transformations in Submerged Soils. In: Nitrogen in Agriculturals Soils. (F. J. Stevenson, ed.), pp. 449-466.

Pidwirny, M. J. 2002. Fundamentals of Physical Geography. Introduction to Biogeography and Ecology, The Nitrogen Cycle. Accessed on June 30, 2003.

(http://www.geog.ouc.bc.ca/physgeog/contents/ 9s.html)

Powlson, D. S. 1993. Understanding the Soil Nitrogen Cycle. Soil Use and Management. 9: 86-84.

Rao, K. P. and D. W. Rains. 1976. Nitrate Absorption by Barley. I. Kinetics. Plant Physiol. 57: $55-58$.

Rorison, I. H. 1980. The Effects of Soil Acidity on Nutrient Availability and Plant Response. In Effects of Acid Precipitation on Terrestrial Ecosystems (T. C. Hutchinson and M. Havas, eds), pp. 283-304. Plenum, New York, NY.

Sabey, B. R. 1969. Influence of Soil Moisture Tension on Nitrate Accumulation in Soils. Soil Sci. Soc. Am. Proc. 33: 263-266.

Sasseville, D. N. and H. A. Mills. 1979. N Form and Concentration: Effects on N Absorption, Growth, and Total N Accumulation with Southern Peas. J. Amer. Soc. Hort. Sci. 104(5): 586-591.

Schroeder, E. D. 1981. Denitrification in Waste Management. In: Denitrification, Nitrification and Atmospheric Nitrous Oxide. pp. 127-133, C. C. Delwiche, Univ. of California, Davis.
Simonne, E. and G. Hochmuth. 2003a. Principles of Fertilization and Irrigation Management for Vegetables Crops Grown in Florida in the BMP Era: Introduction. UF/IFAS, Fla. Coop. Ext. Serv., HS897. (http://edis.ifas.ufl.edu/HS154)

Simonne, E., G. Hochmuth. 2003b. Supplemental Fertilizer Application in the BMP Area for Vegetable. UF/IFAS, Fla. Coop. Ext. Serv., HS906. (http://edis.ifas.ufl.edu/HS163)

Simonne, E. S. and H. A. Mills. 1991. N- form Effects on Nutrition of Watermelon. Hortscience 26(6): 703.

Simonne, E. H., C. Hutchinson, M. Dukes, G. Hochmuth and B., Hochmuth. 2003. Update and Outlook for 2003 of Floridas BMP Program for Vegetable Crops. UF/IFAS, Fla. Coop. Ext. Serv., HS916. (http://edis.ifas.ufl.edu/HS170)

Singh, B. R., A. S. Agarwal and Y. Kanehiro. 1969. Effect of Chloride Salts on Ammonium Nitrogen Release in Two Hawaiian Soils. Proc. Soil Sci. Soc. Am. 33: 556-560.

Somner, M. E. and T. Yamada. 2002. Farming with Acidity. Soil Sci. Plant Anal. 33(15-18): 2467-2496.

Sullivan, D. G., C. W. Wood, W. F. Owsley, M. L. Norfleet, B. H. Wood J. N. Shaw and J. F. Adams. 2003. Ammonia Volatilization from a Swine Waste Amended Bermudagrass Pasture. Commun. Soil Sci. and Plant Anal. 34(11-12): 1499-1510.

Thiagalingam, K., and Y. Kanchiro. 1973. Effects on temperature on nitrogen transformation in four Hawaiian soils. Plant Soil 38: 177-189.

Venkateswarlu, B., and A. V. Rao. 1987. Quantitative Effects of Fields Water Deficits on N2 $\left(\mathrm{C}_{2} \mathrm{H}_{2}\right)$ Fixation in Selected Legumes Grown in the Indian Desert. Biology and Fertility of Soils 5: 18-22.

Volk, B. G. and Loeppert. 1982. Soil organic Matter. In: Handbook of Soils and Climate in Agriculture. (V. J. Kilmer, ed), pp. 211-268. CRC Press, Boca Raton, FL. 
Wang, Q., H. Bryan, W. Klassen, Y. Li and M.

Codallo. 2002. Improved Tomato Production with

Summer Cover Crops and Reduced Irrigation Rates.

Proc. Fla. State Hort. Soc. 115: 202-207.

Welsh, C. E., E. A. Guertal and C. W. Wood. 1996. Highlight of Agricultural Research, Fertility and Fumigation. 43(2). Accessed on July 11, 2003. (http://www.ag.auburn.edu/aaes/communications/ highlights/summer96/index.html)

Westerman, R. L., and F. C. Fucker. 1974.

Effects of Salt and Salt Plus Nitrogen on Labeled

Ammonium. Soil Sci. Soc. Am. Proc. 38: 602-605.

Witzig, J.D. and N.L. Pugh. 2001. 1999-2000

Florida Agricultural Statistics Vegetable Summary.

FDACS, Tallahassee, FL.

Yoshiba, T. 1975. Microbial Metabolism of Flooded Soils. In: Soil Biochemistry. (E. A. Paul and A. D. McLaren, eds.), 3: 83-112. Dekker, New York, NY. 
Table 1. Processes of the $\mathrm{N}$ cycle affected by nitrogen fertilization.

\begin{tabular}{|c|c|c|}
\hline $\begin{array}{l}\text { Processes affected } \\
\text { by fertilization }\end{array}$ & Enhanced by & Reduced by \\
\hline Mineralization & $\begin{array}{l}\text { - Addition of cations, whose ability to stimulate } \\
\text { mineralization follows the same order as their } \\
\text { replacing power on cation exchange sites in } \\
\text { soils. } \\
\mathrm{Al}^{3+}>\mathrm{Fe}^{3+}>\mathrm{Ca}^{2+}>\mathrm{Mg}^{2+}>\mathrm{K}^{+}>\mathrm{Na}^{+} \\
(\text {Singh et al., } 1969 ; \text { Broabent and Nakashima, } \\
1971 ; \text { Agarwal et al., } 1971 \text {; Westerman and } \\
\text { Fucker, 1974; Heilman, 1975; Laura, 1977) } \\
\text { - Adequate source of } \mathrm{C} \text { and } \mathrm{N} \text { for microbial } \\
\text { growth. } \\
-\mathrm{O}_{2}^{2} \\
-\mathrm{High}_{\text {igh temerature }}\end{array}$ & $\begin{array}{l}\text { - Fertilization may influence the activities } \\
\text { and population diversity of the microbial } \\
\text { biomass through changes in microbial } \\
\text { environment. }\end{array}$ \\
\hline Nitrification & $\begin{array}{l}\text { - Addition of } \mathrm{NH}_{4}^{+} \text {or } \mathrm{NO}_{2}^{-} \text {increases } \\
\text { population of nitrifiers (Jones and Hedlin, 1970) }\end{array}$ & $\begin{array}{l}\text { - Nitrification inhibitors: High concentration } \\
\text { of } \mathrm{NH}_{4}^{+}(>800 \mu \mathrm{g} \mathrm{N} / \mathrm{g} \text { of soil) inhibit } \\
\text { activity of microorganisms }\end{array}$ \\
\hline Dentrification & $\begin{array}{l}\text { - Influence on the proportion of gas produced. } \\
\text { At high concentration of } \mathrm{NO}_{3}^{-}, \mathrm{N}_{2} \mathrm{O} \text { is the } \\
\text { predominant gas (Blackmer and Bremmer, } \\
\text { 1978) }\end{array}$ & \\
\hline Plant uptake & $\begin{array}{l}\text { - Split application of granular fertilizer (2 or } 3 \\
\text { side-dresses) } \\
\text { - Weekly or daily fertigation schedules (for drip } \\
\text { irrigation and plasticulture; Simonne and } \\
\text { Hochmuth, 2003a) } \\
\text { - Controlled-release fertilizers (CRFs) } \\
\text { - Actively growing root system }\end{array}$ & $\begin{array}{l}-\mathrm{NH}_{4}^{+} \text {has an inhibitory effect on } \mathrm{NO}_{3}^{-} \\
\text {uptake. } \\
\text { - Lack of oxygen in the rootzone } \\
\text { - Low } \mathrm{N} \text { levels and higher } \mathrm{C} \text { in the soil }\end{array}$ \\
\hline $\begin{array}{l}\text { Ammonia } \\
\text { volatilization }\end{array}$ & $\begin{array}{l}\text { - Application method, such as, no incorporation } \\
\text { of fertilizers (manure and urea). } \\
\text { - Manure characteristics, such as dry matter } \\
\text { content } \\
\text { - Application to soils of fertilizers with low cation } \\
\text { exchange capacity } \\
\text { - High rates of } \mathrm{N} \text { fertilizer (>100 lbs } \\
\mathrm{N} / \mathrm{a}) \text { (Combs, 2000). } \\
\text {-Ammonia volatilization accounts for } 5.5 \% \text { to } \\
12.8 \% \text { of applied } \mathrm{N} \text { as } \mathrm{NH}^{+}-\mathrm{N} \text { or urea } \\
\text { respectively, without additional air circulation of } \\
\text { the mean natural wind speed. The losses } \\
\text { increased to } 33.3 \% \text { with maximum rates } \\
\text { volatilization occur within } 5 \text { days after fertilizer } \\
\text { application (Mattos et al., 2003; Sullivan et al., } \\
\text { 2003). }\end{array}$ & $\begin{array}{l}\text {-Incorporation of fertilizer. When manure is } \\
\text { incorporated, } \mathrm{NH}^{+} \text {can attach to soil } \\
\text { exchange sites thus slowing or stopping the } \\
\text { reactions leading to } \mathrm{NH}_{3} \text { (Combs, 2000). }\end{array}$ \\
\hline
\end{tabular}


Table 2. Processes of the $\mathrm{N}$ cycle affected by irrigation.

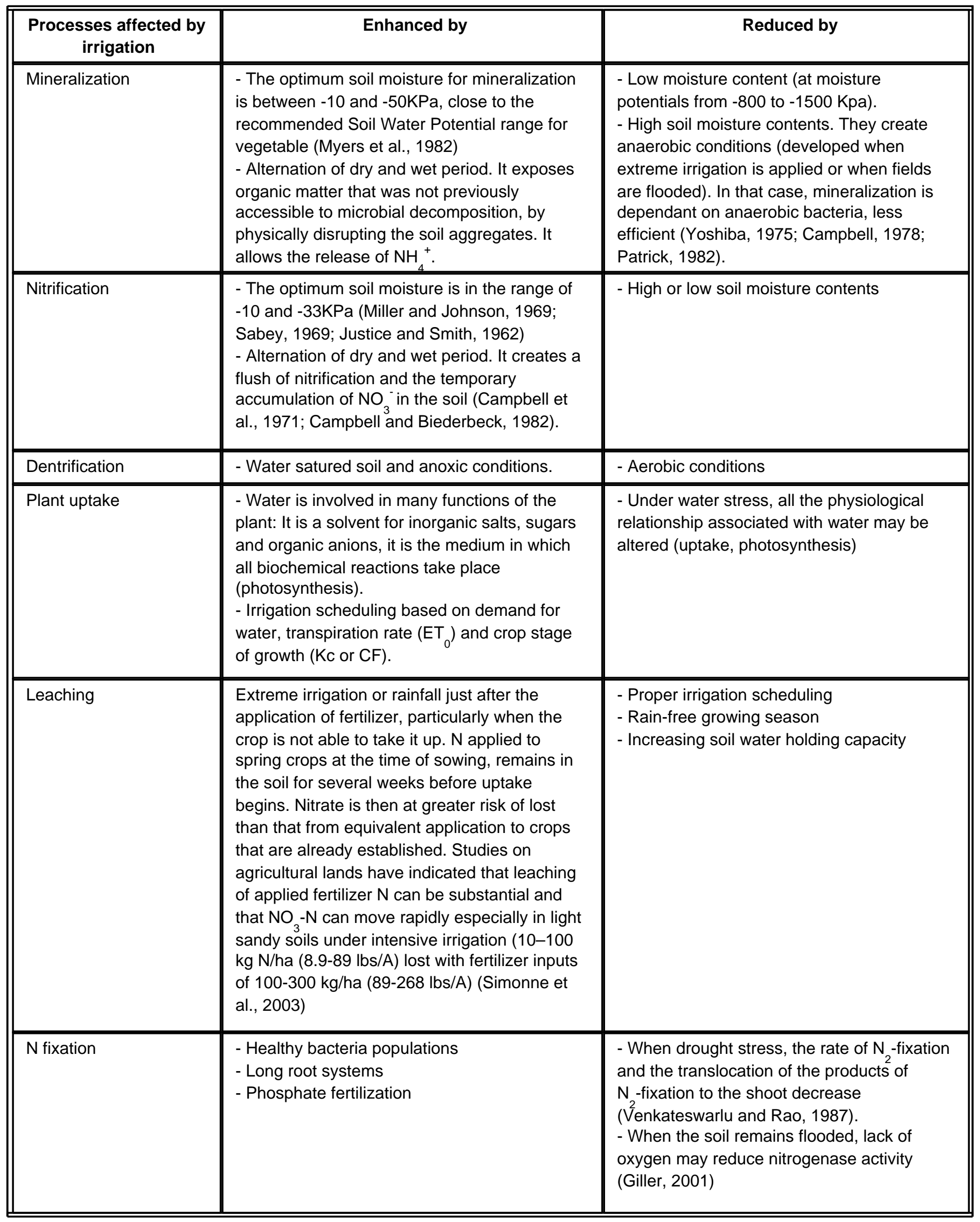


Table 2. Processes of the $\mathrm{N}$ cycle affected by irrigation.

\begin{tabular}{||l|l|l||}
\hline \hline $\begin{array}{c}\text { Processes affected by } \\
\text { irrigation }\end{array}$ & \multicolumn{1}{|c||}{ Enhanced by } & Reduced by \\
\hline Ammonia volatilization & $\begin{array}{l}\text {-Lower moisture. As soil solution evaporates, } \\
\text { the concentration of } \mathrm{NH}_{3} \text { in solution is } \\
\text { increased relative to gaseous } \mathrm{NH}_{3}, \text { and the } \\
\text { equilibrium must be reestablished by losses of } \\
\text { solution } \mathrm{NH}_{3} \text {. (Cowley et al., 1999). }\end{array}$ & -Intensive irrigation \\
\hline
\end{tabular}

Table 3. How polyethylene mulching indirectly affects processes of the $\mathrm{N}$ cycle.

\begin{tabular}{|c|c|}
\hline Processes affected & How mulching affects the $\mathrm{N}$ cycle \\
\hline \multirow[t]{2}{*}{$\begin{array}{l}\text { Mineralization } \\
\text { Nitrification }\end{array}$} & $\begin{array}{l}\text { Mulching improves moisture retention. More uniform soil moisture is maintained (Olson, } \\
\text { 2003). }\end{array}$ \\
\hline & $\begin{array}{l}\text { Mulching increases soil temperature. It creates the optimum range ( } 25 \text { to } 35^{\circ} \mathrm{C} \text { ) for } \\
\text { microbial activity (Justice and Smith, } 1962 \text {; Thiagalingam and Kanchiro, } 1973 \text {; Kowalenko } \\
\text { and Cameroun, 1976). The temperature may raise to } 50^{\circ} \mathrm{C} \text { under plastic mulch without } \\
\text { disturbing indigenous nitrifiers that have temperature optima adapted to tropical areas } \\
\text { (Mahendrappa et al., 1966). }\end{array}$ \\
\hline Plant uptake & $\begin{array}{l}\mathrm{NO}_{3}^{-} \text {uptake becomes greater than } \mathrm{NH}_{4}^{+} \text {uptake at around } 23^{\circ} \mathrm{C} \text { and increases up to } \\
35^{\circ} \mathrm{C} \text { (Frota and Tucker, 1972). }\end{array}$ \\
\hline Leaching & Mulching reduces $\mathrm{NO}_{3}^{-}$leaching due to excessive rainfall. \\
\hline $\mathrm{N}$ fixation & $\begin{array}{l}\text { Most of the } \mathrm{N} \text {-fixation bacteria can grow at temperatures up to } 40^{\circ} \mathrm{C} \text {. Higher or lower } \\
\text { temperatures inhibit } \mathrm{N}_{2} \text {-fixation (Giller, 2001). }\end{array}$ \\
\hline Ammonia volatilization & $\begin{array}{l}\text { As temperature increases above } 75^{\circ} \mathrm{F} \text { the percentage of } \mathrm{NH}_{3} / \mathrm{NH}_{4}^{+} \text {increases and } \\
\text { consequently ammonia volatilization. This increases the partial pressure differences and } \\
\text { encourages volatilization (Cowley et al., 1999). }\end{array}$ \\
\hline
\end{tabular}

Table 4. The C:N ratios of selected organic materials.

\begin{tabular}{|l|c||}
\hline \multicolumn{1}{|c|}{ Material } & Typical C:N ratio $^{\mathrm{b}}$ \\
\hline Microbial tissue & $8: 1^{\mathrm{a}}$ \\
\hline Chicken manure & $9: 1$ to $20: 1^{\mathrm{b}}$ \\
\hline Soil humus & $10: 1^{\mathrm{a}}$ \\
\hline Green legumes & $12: 1^{\mathrm{b}}$ \\
\hline Legume residues & $23: 1^{\mathrm{b}}$ \\
\hline Green grass & $40: 1^{\mathrm{b}}$ \\
\hline Grain straw/dry grass & $80: 1^{\mathrm{b}}$ \\
\hline Pine needles & $225: 1^{\mathrm{b}}$ \\
\hline \hline
\end{tabular}


Table 4. The C: $\mathrm{N}$ ratios of selected organic materials.

\begin{tabular}{||l|c||}
\hline \hline \multicolumn{1}{|c||}{ Material } & Typical C:N ratio ${ }^{\mathrm{b}}$ \\
\hline Sawdust & $400: 1^{\mathrm{a}}$ \\
\hline $\begin{array}{l}{ }^{\mathrm{a}} \text { Source: Volk and Loeppert, 1982. } \\
{ }^{\mathrm{b}} \text { Source: Butler, 2003. }\end{array}$ \\
\hline
\end{tabular}

Table 5. How liming indirectly affects processes of the $\mathrm{N}$ cycle.

\begin{tabular}{|c|c|c|}
\hline $\begin{array}{c}\text { Processed affected } \\
\text { by } \mathrm{pH}\end{array}$ & Effects of $\mathrm{pH}$ & Effects of liming an acidic soil \\
\hline Mineralization & $\begin{array}{l}\text { - Since mineralization of native soil organic } N \text { is } \\
\text { carried out by a diverse range of microflora, the } \\
\text { process does not show a marked sensitivity to } \\
\text { pH (Alexander, 1980). Nonetheless, liming } \\
\text { acidic soils often cause an increase in the } N \\
\text { mineralization rates (Table 6). }\end{array}$ & $\begin{array}{l}\text { - Acceleration of the decay of plant tissues, } \\
\text { simple carbonaceous compounds and soil } \\
\text { organic matter (Alexander, 1977). } \\
\text { - Increase in mineralization (Nyborg and Hoyt, } \\
\text { 1978) (cf Table 6). The greater tolerance of } \\
\text { mineralization than nitrification to low pH is } \\
\text { reflected in the finding that ammonium is } \\
\text { generally the dominant form of } \mathrm{N} \text { in acidic } \\
\text { soils while nitrate predominates in nonacidic } \\
\text { soils (Haynes and Goh, 1978; Rorison, 1980). }\end{array}$ \\
\hline Nitrification & $\begin{array}{l}\text { - In soils of } \mathrm{pH} \text { above } 7.5 \text {, toxic levels of } \mathrm{NH}_{3} \\
\text { may result in the inhibition of the activity of } \\
\text { Nitrobacter and in the accumulation of } \mathrm{NO}^{-} \\
\text {that cannot be transformed in } \mathrm{NO}^{-} \text {. The lower } \\
\text { limit for autotrophic nitrification is found around } \\
\mathrm{pH} 4.5 \text {. }\end{array}$ & $\begin{array}{l}\text { - Increases nitrification process by creating } \\
\text { optimum } \mathrm{pH}(\mathrm{pH}=6.5 \text { to } 7.5) \text {. }\end{array}$ \\
\hline Plant nutrient uptake & $\begin{array}{l}\text { - At } \mathrm{pH}=4 \text { to } 5 \text { maximum absorption of } \mathrm{NO}_{3}^{-} \\
\text {occurs (Rao and Rains, 1976), which will result } \\
\text { in an increase of rhizosphere } \mathrm{pH} \text { (efflux of } \mathrm{H}^{+} \text {in } \\
\text { exchange for } \mathrm{NH}_{4}^{+} \text {). } \\
\text { - } \mathrm{At} \mathrm{pH}=7 \text { to } 8 \text { maximum absorption of } \mathrm{NH}_{4}^{+} \\
\text {occurs (Rao and Rains, 1976), which will result } \\
\text { in a decrease of the rhizosphere } \mathrm{pH} \text { (efflux of } \\
\mathrm{HCO}_{3}^{-} \text {or } \mathrm{OH}^{-} \text {in exchange for } \mathrm{NH}_{4}^{+} \text {). }\end{array}$ & $\begin{array}{l}\text { - Liming to the } 6.0 \text { to } 6.5 \mathrm{pH} \text { range increases } \\
\text { the availability of essential nutrients. } \\
\text { - Liming reduces the risk of aluminum and } \\
\text { manganese toxicity. } \\
\text { - Liming adds } \mathrm{Ca} \text { and } \mathrm{Mg} \text { to the root zone. }\end{array}$ \\
\hline $\begin{array}{l}\text { Ammonia } \\
\text { volatilization }\end{array}$ & $\begin{array}{l}\text { - As } \mathrm{pH} \text { increases, the equilibrium ratio of } \mathrm{NH}_{3} \text { : } \\
\mathrm{NH}_{4}^{+} \text {in solution increases, and volatilization is } \\
\text { more likely to occur because an increase in } \mathrm{NH}_{3} \\
\text { in solution results in an inequilibrium between } \\
\text { liquid } \mathrm{NH}_{3} \text { and gaseous } \mathrm{NH}_{3} \text {. }\end{array}$ & $\begin{array}{l}\text { - Adding lime and increasing the } \mathrm{pH} \text { increase } \\
\text { the } \mathrm{NH}_{3}: \mathrm{NH}_{4}^{+} \text {ratio. }\end{array}$ \\
\hline
\end{tabular}


Table 6. The mineralization of organic nitrogen in 40 soils incubated with or without lime ${ }^{z, y}$.

\begin{tabular}{|c|c|c|c|}
\hline Treatment & & \multicolumn{2}{|c|}{ Organic $\mathbf{N}$ mineralized in 120 days } \\
\hline \multirow[t]{2}{*}{ No lime } & Average & 34 & 1.6 \\
\hline & Range & -1 to 136 & -0.1 to 3.8 \\
\hline $\operatorname{Lime}^{x}$ & Average & 72 & 3.5 \\
\hline \multicolumn{4}{|c|}{$\begin{array}{l}{ }^{\mathrm{z}} \text { Source: Nyborg and Hoyt (1978) } \\
\text { y Soils sample ranged in texture from sandy loam to clay, } \mathrm{pH}(0.1 \mathrm{M} \mathrm{CaCl}) \text { from } 4.0 \text { to } 5.6 \text { (average 5.0) and in total } \mathrm{N} \\
\text { content from } 0.076 \text { to } 0.458 \% \text { (average } 0.21 \%) \text {. } \\
{ }^{\mathrm{x}} \text { lime added to raise soil } \mathrm{pH} \text { to } 6.7\end{array}$} \\
\hline
\end{tabular}

Table 7. Supporting research, expected impact on water quality and benefits of proposed BMPs for vegetable crops grown in Florida. ${ }^{z}$

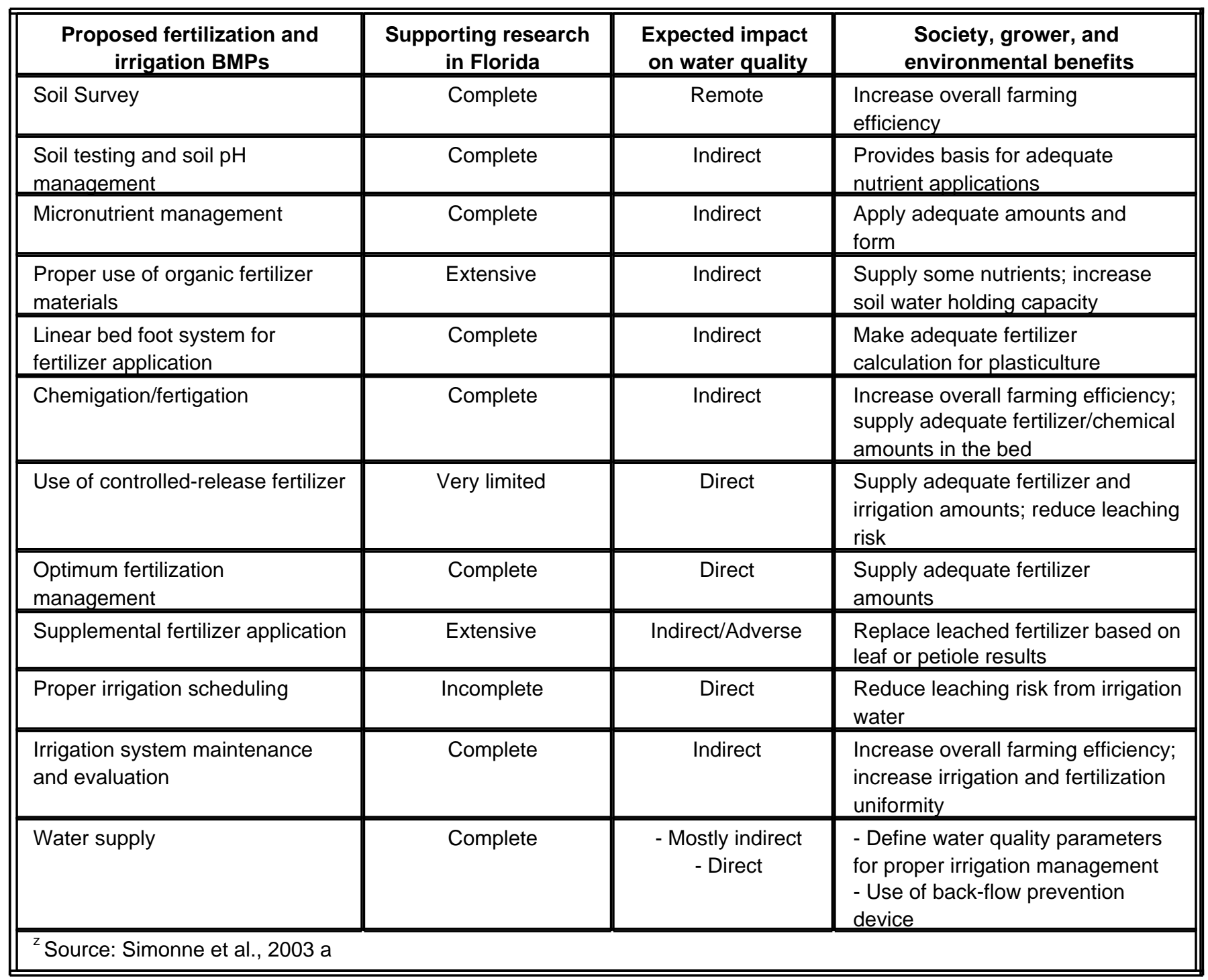


Table 8. Major irrigation and nutrient-management practices that aim at reducing the negative consequences of alteration of the $\mathrm{N}$ cycle in vegetable fields ${ }^{2}$.

\begin{tabular}{|c|c|c|c|}
\hline Cultural Practice & Working definition & Things to do: BMPs & $\begin{array}{l}\text { Things to avoid: } \\
\text { potential pitfalls }\end{array}$ \\
\hline $\begin{array}{l}\text { Crop } \\
\text { Establishment }\end{array}$ & $\begin{array}{l}\text { - Crop establishment is the } \\
\text { process by which an initial amount } \\
\text { of irrigation water is delivered to a } \\
\text { seed or seedling in the fields to } \\
\text { ensure that it will become } \\
\text { well-established. }\end{array}$ & $\begin{array}{l}\text { - Consider weather forecast. } \\
\text { Irrigation-water needs may be } \\
\text { smaller. } \\
\text { - Consider using drip irrigation } \\
\text { and/or tailwater recovery } \\
\text { systems, to make good use of } \\
\text { irrigation water. } \\
\text { - Consider using soil } \\
\text { moisture-determination } \\
\text { equipment or techniques such as } \\
\text { tensiometers so that } \\
\text { over-watering of fields is } \\
\text { minimized. } \\
\text { - Evaluate the different types of } \\
\text { soils on your farm. }\end{array}$ & $\begin{array}{l}\text { - Do not leave irrigation } \\
\text { pump stations and systems } \\
\text { unsupervised during crop } \\
\text { establishment. } \\
\text { - Do not irrigate for crop } \\
\text { establishment during or } \\
\text { immediately after a storm } \\
\text { event. }\end{array}$ \\
\hline $\begin{array}{l}\text { Supplemental } \\
\text { fertilizer } \\
\text { application }\end{array}$ & $\begin{array}{l}\text { - Supplemental fertilizer is that } \\
\text { fertilizer which is applied in addition } \\
\text { to the crop nutrient requirement } \\
\text { (CNR) during the growing season } \\
\text { in order to replace fertilizer } \\
\text { nutrients lost via leaching. } \\
\text { - If the fertilizer component of the } \\
\text { CNR is properly managed to } \\
\text { minimize fertilizer losses, it is } \\
\text { unlikely that additional } \\
\text { supplemental fertilizer will be } \\
\text { needed. }\end{array}$ & $\begin{array}{l}\text { - Manage CNR properly to avoid } \\
\text { leaching losses. } \\
\text { - Make a supplemental application } \\
\text { of } \mathrm{N} \text { and /or } \mathrm{K} \text { when rainfall } \\
\text { exceeds } 3 \text { inches in } 3 \text { days or } 4 \\
\text { inches in } 7 \text { days. } \\
\text { - Where plastic mulch is used, } \\
\text { supplemental application can be } \\
\text { made through the mulch using a } \\
\text { liquid-injection wheel, or by the } \\
\text { drip irrigation system. }\end{array}$ & $\begin{array}{l}\text { - Avoid adding } \\
\text { supplemental or side-dress } \\
\text { fertilizer to row crops } \\
\text { before a forecasted storm } \\
\text { event of significant } \\
\text { magnitude. }\end{array}$ \\
\hline Double cropping & $\begin{array}{l}\text { - Successive cropping of existing } \\
\text { mulched beds is a good practice } \\
\text { that makes effective use of } \\
\text { polyethylene mulch, soil fumigant } \\
\text { and residual fertilizer. }\end{array}$ & $\begin{array}{l}\text { - Be observant for any nutrient } \\
\text { deficiencies in the first crop. } \\
\text { - Take a representative soil } \\
\text { sample in the bed away from any } \\
\text { first-crop fertilizer bands. } \\
\text { - Use either drip irrigation or an } \\
\text { injection wheel to apply the } \\
\text { fertilizer. } \\
\text { - Apply an amount of } \mathrm{N} \text { equal to } \\
\text { the crops own nutrient } \\
\text { requirement as long as } \mathrm{N} \text { was not } \\
\text { applied in excess of the nutrient } \\
\text { requirement for the first crop. }\end{array}$ & $\begin{array}{l}\text { - Do not add extra fertilizer } \\
\text { when planting the first crop } \\
\text { with the misconception that } \\
\text { this fertilizer will aid growth } \\
\text { at the second crop. } \\
\text { - Do not exceed the } \\
\text { fertilizer recommendations } \\
\text { for the first or second crop. }\end{array}$ \\
\hline $\begin{array}{l}\text { Proper use of } \\
\text { organic fertilizer } \\
\text { materials }\end{array}$ & $\begin{array}{l}\text { - The key to proper use of } \\
\text { organic-material fertilizers comes } \\
\text { in the knowledge of the nutrient } \\
\text { content and the decomposition } \\
\text { rate of the materials. }\end{array}$ & $\begin{array}{l}\text { - Make samples of the } \\
\text { representative organic material, } \\
\text { near to the time of application. } \\
\text { - Base the application rate on the } \\
\text { specific nutrient content from the } \\
\text { laboratory analysis and on } \\
\text { individual crop requirements. }\end{array}$ & $\begin{array}{l}\text { - Do not apply excessive } \\
\text { amounts of organic } \\
\text { fertilizer materials, since } \\
\text { excess nutrients will be } \\
\text { released, possibly leading } \\
\text { to contamination of nearby } \\
\text { water sources. }\end{array}$ \\
\hline
\end{tabular}


Table 8. Major irrigation and nutrient-management practices that aim at reducing the negative consequences of alteration of the $\mathrm{N}$ cycle in vegetable fields ${ }^{2}$.

\begin{tabular}{|c|c|c|c|}
\hline Cultural Practice & Working definition & Things to do: BMPs & $\begin{array}{l}\text { Things to avoid: } \\
\text { potential pitfalls }\end{array}$ \\
\hline $\begin{array}{l}\text { Controlled-release } \\
\text { fertilizers (CRFs) }\end{array}$ & $\begin{array}{l}\text { - CRFs are sphere-like prills made } \\
\text { of a water-soluble fertilizer that } \\
\text { degrade based on soil temperature } \\
\text { and/or moisture. The time of } \\
\text { release is determined by coating } \\
\text { composition and thickness if } \\
\text { coating, chemical composition, and } \\
\text { the condition of the soil (mainly } \\
\text { temperature and moisture level). }\end{array}$ & $\begin{array}{l}\text { - Test the soil for nutrient } \\
\text { availability before using CRFs. } \\
\text { - Match the CRFs parameters } \\
\text { (release time, release } \\
\text { temperature) with the crop and } \\
\text { field conditions. }\end{array}$ & $\begin{array}{l}\text { - Do not exceed the soil } \\
\text { test-based recommended } \\
\text { rate. } \\
\text { - Do not place CRFs on the } \\
\text { soil surface. }\end{array}$ \\
\hline $\begin{array}{l}\text { Optimum } \\
\text { fertilization } \\
\text { management and } \\
\text { application }\end{array}$ & $\begin{array}{l}\text { - Optimum fertilization } \\
\text { management is the judicious } \\
\text { application of fertilizers to meet the } \\
\text { crop nutrient requirement without } \\
\text { adding excess nutrients. } \\
\text { - Careful use of fertilizers will save } \\
\text { money and prevent unnecessary } \\
\text { environmental impacts. }\end{array}$ & $\begin{array}{l}\text { - Know the CNR for } \mathrm{N} \text { as } \\
\text { specified in IFAS fertilization } \\
\text { recommendations and target this } \\
\text { amount for total crop N } \\
\text { fertilization. } \\
\text { - Calibrate fertilizer application } \\
\text { accurately so that fertilizer is } \\
\text { applied in the right zone, to a } \\
\text { correct amount. } \\
\text { - Manage } \mathrm{N} \text { carefully, since } \mathrm{N} \text { is } \\
\text { mobile in sandy soils. Splitting the } \\
\text { fertilizer applications will help } \\
\text { reduce both leaching and the } \\
\text { potential for soluble salt damage } \\
\text { to the plants. }\end{array}$ & \\
\hline Tissue testing & $\begin{array}{l}\text { - It is the analysis and diagnosis of } \\
\text { the plants nutritional status based } \\
\text { on its chemical composition. It } \\
\text { allows having a more efficient } \\
\text { fertilizer management and } \\
\text { minimizing impacts on the } \\
\text { environment. }\end{array}$ & $\begin{array}{l}\text { - Begin the plant sampling soon } \\
\text { after the crop is established and } \\
\text { continue at regular intervals. }\end{array}$ & $\begin{array}{l}\text { - Do not sample only one } \\
\text { part of the field but } \\
\text { different areas, to be more } \\
\text { representative. }\end{array}$ \\
\hline Fertigation & $\begin{array}{l}\text { - Precision application, known as } \\
\text { fertigation, follows plant needs } \\
\text { more closely than traditional } \\
\text { fertilizer methods and helps reduce } \\
\text { nutrient leaching. }\end{array}$ & $\begin{array}{l}\text { - Locate the injector so that a } \\
\text { minimum amount of water is } \\
\text { delivered to the field before the } \\
\text { fertilizer reaches the crop. This } \\
\text { will reduce the potential of over } \\
\text { watering crop with associated } \\
\text { leaching. } \\
\text { - Use split application to prevent } \\
\text { over-irrigation and leaching. }\end{array}$ & $\begin{array}{l}\text { - Avoid excessive irrigation } \\
\text { that could cause nutrients } \\
\text { to be leached below the } \\
\text { root zone. }\end{array}$ \\
\hline
\end{tabular}


Table 9. Processes of the $\mathrm{N}$ cycle, cultural practices that affect them, irrigation and nutrient BMPs that can reduce the consequence of the alterations of the $\mathrm{N}$ cycle.

\begin{tabular}{|c|c|c|c|}
\hline Step & Nitrogen cycle & $\begin{array}{c}\text { Cultural practices that affect } \\
\text { the cycle }\end{array}$ & Irrigation and nutrient BMPs \\
\hline 1 & Mineralization & $\begin{array}{l}\text { - Fertilization } \\
\text { - Fumigation } \\
\text { - Irrigation } \\
\text { - Plastic mulching and bedding } \\
\text { - Liming } \\
\text { - Cover-crop and crop residues }\end{array}$ & \multirow{7}{*}{$\begin{array}{l}\text { - Soil survey } \\
\text { - Soil testing and soil pH } \\
\text { - Proper micronutrient fertilization } \\
\text { - Proper use of organic fertilizer } \\
\quad \text { materials } \\
\text { - Fertigation } \\
\text { - Controlled-release fertilizer (CRF) } \\
\text { - Optimum fertilization management } \\
\text { - Supplemental fertilizer application } \\
\text { - Irrigation scheduling } \\
\text { - Tissue testing } \\
\text { - Double cropping } \\
\text { - Crop establishment }\end{array}$} \\
\hline 2 & Adsorption/desorption & $\begin{array}{l}\text { - Fertilization } \\
\text { - Cover crops } \\
\text { - Chicken litter }\end{array}$ & \\
\hline 3 & Nitrification & $\begin{array}{l}\text { - Fertilization } \\
\text { - Manure } \\
\text { - Fumigation } \\
\text { - Irrigation } \\
\text { - Plastic mulching } \\
\text { - Liming }\end{array}$ & \\
\hline $4 a$ & Plant nutrient uptake & $\begin{array}{l}\text { - Fertilization } \\
\text { - Irrigation } \\
\text { - Liming }\end{array}$ & \\
\hline $4 b$ & Nitrate leaching & $\begin{array}{l}\text { - Fertilization } \\
\text { - Irrigation } \\
\text { - Cover-crop } \\
\text { - Plastic mulching }\end{array}$ & \\
\hline $4 c$ & Dentrification & $\begin{array}{l}\text { - Fertilization } \\
\text { - Irrigation } \\
\text { - Plastic mulching } \\
\text { - Cover-crop and crop residues }\end{array}$ & \\
\hline 5 & Nitrogen fixation & $\begin{array}{l}\text { - Fertilization } \\
\text { - Irrigation } \\
\text { - Plastic mulching }\end{array}$ & \\
\hline
\end{tabular}

